\title{
FINTECH LENDING
}

Tobias Berg

Andreas Fuster

Manju Puri

Working Paper 29421

http://www.nber.org/papers/w29421

\author{
NATIONAL BUREAU OF ECONOMIC RESEARCH \\ 1050 Massachusetts Avenue \\ Cambridge, MA 02138 \\ October 2021
}

Draft in preparation for Annual Review of Financial Economics. We thank Jon Frost, Leonardo Gambacorta, Christine Laudenbach, and Philipp Schnabl for helpful comments and suggestions, and Lauren Lambie-Hanson for help with the U.S. mortgage data. All errors are our own. The views expressed herein are those of the authors and do not necessarily reflect the views of the National Bureau of Economic Research.

NBER working papers are circulated for discussion and comment purposes. They have not been peer-reviewed or been subject to the review by the NBER Board of Directors that accompanies official NBER publications.

(C) 2021 by Tobias Berg, Andreas Fuster, and Manju Puri. All rights reserved. Short sections of text, not to exceed two paragraphs, may be quoted without explicit permission provided that full credit, including $\left({ }^{\circ}\right.$ notice, is given to the source. 
FinTech Lending

Tobias Berg, Andreas Fuster, and Manju Puri

NBER Working Paper No. 29421

October 2021

JEL No. G2,G20,G21,G23

\section{$\underline{\text { ABSTRACT }}$}

In this paper, we review the growing literature on FinTech lending - the provision of credit facilitated by technology that improves the customer-lender interaction or lenders' screening and monitoring of borrowers. FinTech lending has grown rapidly, though in developed economies like the U.S. it still only accounts for a small share of total credit. An increase in convenience and speed appears to have been more central to FinTech lending's growth than improved screening or monitoring, though there is certainly potential for the latter, as is the case for increased financial inclusion. The COVID-19 pandemic has shown potential vulnerabilities of FinTech lenders, although in certain segments they have displayed rapid growth.

\section{Tobias Berg}

Frankfurt School of Finance \& Management

t.berg@fs.de

Andreas Fuster

Swiss Finance Institute @ EPFL

Quartier UNIL-Dorigny

Extranef 216

Lausanne CH-1015

Switzerland

and CEPR

andreas.fuster@gmail.com
Manju Puri

Fuqua School of Business

Duke University

100 Fuqua Drive

Durham, NC 27708-0120

and NBER

mpuri@duke.edu 


\section{Introduction}

The last decade has brought FinTech lending to the forefront of debates among academics, regulators, and policymakers. In some areas, such as the U.S. mortgage market, FinTech lenders have established themselves as major players. Other business models have disappointed - a particularly vivid example is the closing of the former peer-to-peer lending platform LendingClub to retail investors in 2020. New FinTech business models are currently in the spotlight, most notable the so-called buy-now-pay-later (BNPL) firms, with Swedish BNPLprovider Klarna breaking into the ranks of the five most valuable banks in Europe.

In this paper, we review the emerging scientific literature on FinTech lending and point out directions for further research. We define FinTech lending as the use of technology to provide lending products. The use of technology has two main flavors: first, to improve the customer-lender interaction (for example, with a fully online application process), giving rise to a better user experience, faster processing times and lower operational costs. Second, technology can be used to improve screening or monitoring, for example, by using alternative data sources or machine learning methods.

In Section 2, we provide estimates of the market size of FinTech lending as well as statistics on the market capitalization (or valuation in case of private firms) of key FinTech players. This section provides evidence about the importance of FinTech lending in various lending markets, as well as market expectations regarding which business models are seen as particularly promising going forward.

In Section 3, we discuss the empirical evidence on both flavors of FinTech lending. We summarize the recent literature on lending efficiency of FinTech lenders as well as the performance of FinTech lenders in screening and monitoring borrowers. We also provide insights into the human-vs.-machine debate, that is, the question of whether humans have an edge in screening or monitoring borrowers vis-à-vis well-trained algorithms.

Section 4 discusses an important issue at the forefront of the current debate: What are the real effects of FinTech lending - in particular, who are the losers and who are the winners of FinTech lending? We discuss evidence both on the access to credit (extensive margin) as well as changes in pricing in the cross-section of borrowers (intensive margin). We also discuss recent evidence on the impact of FinTech lending on discrimination and how FinTech lending interacts with data privacy concerns.

Section 5 assesses the performance of FinTech lending during the COVID-19 pandemic, which was arguably the first major shock to this sector and thus provides insights into the 
resilience of these new lending models. Section 6 concludes with an outlook for future developments and priority areas for further research.

Our aim is not to exhaustively cover the rapidly growing academic literature in this area, but to provide some emerging takeaways and point out areas where we think additional evidence would be particularly valuable. We focus exclusively on FinTech in lending markets. Within lending markets, we focus on lending to households and firms for investment or consumption purposes, we omit securities lending and lending in the nascent field of cryptocurrency markets. Other recent overview articles - in some cases with a broader focus include Agarwal \& Zhang (2020), Allen et al. (2021), Thakor (2020), and Vives (2019).

\section{Definition and market size}

\subsection{Definition of FinTech lending}

In its broadest definition, FinTech refers to the use of technology to provide financial services (see, e.g., BIS, 2018; and FSB, 2019). More specifically, FinTech lending can be defined based on the nature of the customer-lender interaction or on the technology that is used to screen and monitor borrowers. ${ }^{1}$

- Customer-lender interaction: The lending process can give rise to the FinTech label if the customer-lender interaction is purely app-based or purely online (see, for example, Buchak et al. 2018; Fuster et al. 2019). Such a lending process can lower processing times, lower operational costs, and improve the user experience. It increases lender elasticity to demand shocks and decreases errors that may arise from human interaction in the lending process. It may be particularly attractive to borrowers that value convenience over personal interaction and advice.

- Screening and monitoring: The screening and monitoring technology can give rise to the FinTech label if a lender uses technology to improve traditional bank models for screening and/or monitoring of borrowers. Technology can either be used to expand the set of information (for example the use of digital footprints, see Berg et al. 2020), or by applying machine learning algorithms to improve the information content of a given set of information (see Fuster et al. 2021). Such a use of technology can improve default and recovery rates, alter price and non-price terms, and affect the set of borrowers that get access to finance.

\footnotetext{
${ }^{1}$ Furthermore, FinTech can help to lower search costs for borrowers and lenders, thereby allowing lenders to enter new geographic markets (see Thakor, 2020, and Basten \& Ongena, 2020).
} 
Many traditional banks have invested in technology, allowing loan applications to be handled online and/or using non-standard data sources to screen and monitor borrowers. Many researchers therefore add additional criteria to ensure that traditional banks do not fall under the FinTech label. These qualifications include the requirement for FinTech lenders to come from outside the incumbent banking system (see, for example, Cornelli et al. 2020 and Ziegler et al. 2021), or a requirement that lenders do not take deposits to qualify as FinTech lenders (see, for example, Gopal \& Schnabl, 2021).

Researchers should be aware that there is not a unique definition for FinTech lending and that many traditional banks have invested heavily into technology, so that differences between FinTech firms and traditional banks tend to have attenuated over time. The current practice of defining FinTech lenders uses a mix of features that include the characteristics of the customer-lender interaction, the screening and monitoring technology, as well as additional qualifications that are not directly linked to the underlying use of technology and that instead also reflect differential regulatory treatment.

\subsection{Market size - U.S. market}

We start by providing an overview about the market size of FinTech lending in the U.S. The U.S. serves as a natural starting point because it is a major market for FinTech lending, and data availability and quality are better than in most other countries. Table 1 provides U.S. lending volumes both for the entire market and for FinTech lending. Panel A provides the amount of outstanding loans at the end of 2020 for three key lending segments: mortgage lending (USD 16.8trn) $)^{2}$, consumer credit (USD 4.2trn) and business lending (USD 2.6trn). Panel B and Panel $\mathrm{C}$ provide estimates for FinTech lending. The statistics on FinTech lending in Panel B and C are based on new lending, as opposed to the stock of outstanding loans in Panel A. Data on the stock of FinTech lending is typically not easy to collect and unreliable, see Ziegler et al. (2021) for details. Two key takeaways stand out.

[Table 1]

Takeaway 1: FinTech lending currently constitutes a small share of overall lending in the U.S., but FinTech growth rates outpace lending growth rates for the entire market.

\footnotetext{
${ }^{2}$ Of these, 11.7trn are residential mortgages on 1- to 4-unit properties, which is the main segment where FinTech mortgage lenders are active.
} 
FinTech lending is generally dwarfed by the amount of outstanding loans (held in the traditional banking sector or securitized). In the mortgage market, where FinTech lending (mainly Rocket Mortgage) has gained a significant presence, the FinTech market share of new lending (incl. refinancings) reached a new high of about $14 \%$ in $2020 .{ }^{3}$ Nevertheless, even in this banner year, the annual FinTech lending volume amounted to only approximately $3.5 \%$ of the outstanding stock of mortgages. In all other areas, the importance of FinTech lending is significantly lower. FinTech lending can be a major player in certain subcategories; however, these subcategories are often not large from an overall market perspective. ${ }^{4}$ Growth rates of FinTech lending have been higher than growth rates in the traditional banking system in the U.S. over the past years. Going forward, the importance of FinTech lending for capital allocation, financial stability, and macroeconomic outcomes is likely to depend on whether FinTech lenders continue to serve specialized niches, or are able to gain a significant presence in major parts of the U.S. lending market aside from residential mortgages.

\section{Takeaway 2: FinTech lending has gained double-digit market share in the mortgage market. FinTech lending growth rates are particularly high in the buy-now-pay-later (BNPL) market, while marketplace consumer lending was important early on, but has not} displayed much growth in recent years.

FinTech lending has clearly gained a strong presence in the mortgage market, with a FinTech lender, Rocket Mortgage, being the largest mortgage originator in the U.S. The U.S. mortgage market is an unusual credit market in that most loans are securitized via the government-backed firms Fannie Mae, Freddie Mac, and Ginnie Mae, who also insure the loans' default risk and effectively dictate the underwriting criteria. The key comparative advantage of FinTech lenders in this market therefore hinges on a more efficient process, and not on screening customers with alternative data or machine learning algorithms (see Fuster et al. 2019).

Interestingly, marketplace lending - which has been heavily researched in academic papers - plays a relatively minor role in the FinTech lending space. LendingClub and Prosper, for example, have not expanded lending volumes over the 2016-2020 period. Marketplace

\footnotetext{
${ }^{3}$ This calculation uses a list of ten FinTech lenders from Jagtiani et al. (2021), which in turn combines and updates the lists from Buchak et al. (2018) and Fuster et al. (2019). Given that some existing lenders may have transformed into FinTech lenders in recent years, and some new entrants are not part of these lists yet, the 14\% market share most likely understates the "true" market share of current FinTech mortgage lenders.

${ }^{4}$ A specific example is provided by TransUnion (2019) who state that FinTechs have gained a market share of $38 \%$ in the "unsecured personal loan" market. The volume of unsecured personal loans, according to TransUnion (2019), is USD 138bn and thus the unsecured personal loan market comprises less than $5 \%$ of consumer credit volume in the U.S.
} 
lending has evolved over time from a peer-to-peer business model, where retail investors fund retail loans, to a model that relies heavily on institutional funding. Hildebrandt et al. (2017) show evidence of adverse selection for retail lenders in the early days of peer-to-peer lending in Prosper, when sophisticated investors acting as group leaders certified the loans. Balyuk and Davydenko (2019) show that in recent years over 90\% of the loans on Prosper are done by institutions. ${ }^{5}$ LendingClub has recently shut down its platform for retail investors. ${ }^{6}$

In two segments, FinTech lending significantly expanded over the 2016-2020 period. First, FinTech business lending expanded 43\% per annum and now stands at USD $31 \mathrm{bn}$ in 2020 (Ziegler et al. 2021). The majority of FinTech lending is not provided by marketplace lenders, but by balance sheet lenders (see Ziegler et al. 2021). ${ }^{7}$ Second, we estimate FinTech lending in the BNPL (buy-now-pay-later) segment to be USD 25bn in the U.S., with growth rates $>100 \%$ over the last four years. There has been little academic research into the BNPL segment, even though BNPL has already drawn significant attention by regulators in the U.S. and other countries (Lott, 2021; Woolard, 2021). ${ }^{8}$

The market shares and growth prospects of various FinTech business models are also reflected in their market capitalizations (see Table 2). Rocket has a market capitalization of USD 34bn and the valuations of the three major BNPL providers varies between USD 15bn and USD 46bn. In contrast, the market capitalization of the well-known marketplace lenders LendingClub (USD 2.8bn), Prosper (< USD 1bn), and OnDeck (USD 0.1bn) is an order of magnitude smaller. That said, a company with a similar business model, Upstart, has seen a rapid rise in valuation over the course of 2020 and stood at 16.8bn as of end of August 2020.9 Overall, the statistics on market capitalization support the fact presented above: while many marketplace lenders have struggled to cope with expectations, FinTech lending in the mortgage market as well as in the BNPL segment are on the rise. ${ }^{10}$

\footnotetext{
5 Similarly, Vallee \& Zeng (2019) document that in 2017 only 13\% of LendingClub's investors were retail investors, with the majority of funds coming from institutional investors (55\%) and managed accounts (29\%). See Morse (2015) for a description of the early phase of marketplace lending.

${ }^{6}$ See https://www.lendacademy.com/lendingclub-closing-down-their-platform-for-retail-investors/ (accessed Sep 2, 2021).

${ }^{7}$ Relative to household lending, there has been less research on FinTech business lending in the U.S., although papers are starting to emerge (Barkley \& Schweitzer, 2021; Balyuk et al. 2020; Gopal \& Schnabl, 2021).

${ }^{8}$ Berg et al. (2020) analyze lending in the BNPL market with a focus on the screening technology used in this segment of the market. However, there has been little research into the consequences of the rise in BNPL lending on consumers.

${ }^{9}$ Upstart evaluates applicant credit risk for partner banks who originate personal loans and car refinance loans, which they then either hold on balance sheet or sell off to institutional investors.

10 While we focus on firms that are directly active in the lending business, FinTech has impacted many intermediary steps in the lending process, with independent firms often providing services to bank and nonbank lenders (see Choi et al.. 2019, for an overview in the mortgage segment). As an example, Black Knight, a software, data and analytics provider in this area, has a market capitalization of $11.7 \mathrm{bn}$ as of August 2021.
} 
[Table 2]

\subsection{Market size - Non-U.S. markets}

Claessens et al. (2018), Cornelli et al. (2020) and Ziegler et al. (2021) provide excellent overviews of FinTech credit volumes and other alternative forms of lending globally. The primary data comes from an alternative finance survey conducted by the Cambridge Center for Alternative Finance (CCAF), capturing 703 firms as of 2020.

Cornelli et al. (2020) identify a key trend globally: the rise of BigTech credit. BigTech credit is defined as lending by large companies whose primary business is technology. BigTech credit growth has outpaced FinTech credit and - as of 2019 - makes up three quarters of the combined BigTech plus FinTech credit volume worldwide. We refer the reader to FSB (2019), Frost et al. (2019), Stulz (2019), and Cornelli et al. (2020) for an in-depth discussion.

Ziegler et al. (2021) provide cross-country statistics and analysis of alternative lenders, including FinTech lending. The U.S. is the second largest market for FinTech lending worldwide, dominated only by China (though volumes in China are declining due to regulatory changes in China). Four countries have a larger market share for FinTech lending than the United States (China, Indonesia, Korea, Kenya). FinTech market share tends to be higher in countries with higher GDP per capital, in countries with lower banking competition, and in countries with less stringent banking regulation (Claessens et al. 2018; Cornelli et al. 2020). However, high-quality data on both FinTech and traditional lending is sometimes scarce in many countries, and cross-country drivers of FinTech penetration and the real consequences of higher FinTech penetration clearly remain an important area for future research.

\section{Differences between FinTech and traditional bank business models}

\subsection{Customer-lender interaction}

Takeaway 3: Key competitive advantages of FinTech lenders are faster processing times and an improved user experience. On the one hand, FinTech lenders can thus provide loans more elastically when credit demand changes. On the other hand, instant borrowing via FinTech lenders has the potential to induce overborrowing by naïve consumers. 
At the heart of many FinTech business models lies an improvement in the process by which customers and lenders interact. FinTech lenders have streamlined the lending process, thereby improving user experience, accelerating processing times, and minimizing (error-prone) human input. Three examples illustrate this innovation. First, the key benefit that Rocket Mortgage emphasizes on its webpage is neither pricing nor credit access, but a streamlined process ("Our streamlined application syncs with your bank to get you accurate numbers, fast."). ${ }^{11}$ Second, in a survey conducted by Klarna, $50 \%$ of smartphone users said it is too much trouble to type in a bank account number or social security number to qualify for a loan. Buy-now-pay-later (BNPL) firms have therefore implemented instant loans requiring just a name and an email address, and using these together with digital footprints collected from applicants' online behavior to make a credit decision (American Banker, 2017; Berg et al. 2020). Third, payment firms like Square and Paypal offer short-term loans to merchants. These so-called merchant cash advances (MCAs) are not necessarily cheap (rates can exceed 10\%), but the convenience of getting a loan is the key. Square, for example, markets its lending products by stating "No long forms to fill out" and "You'll usually know if you're approved right away". ${ }^{12}$

The anecdotal evidence cited above has also been shown in rigorous academic studies. Buchak et al. (2018) point out that FinTech lenders seem to offer convenience rather than cost savings to borrowers, while Fuster et al. (2019) document a 20\% improvement in processing time in the context of U.S. mortgage lending. Hau et al. (2021) note that firms active on Alibaba's platform can fill out a credit application in 3 minutes, the approval takes 1 second, and the process involves zero human interaction (3-1-0 model). Berg et al. (2020) show that a German E-commerce firm extends credit to its customers requiring only the name, address, and email address of the customers to make a credit decision. In all cases, the key innovation is not necessarily a better credit decision, but more convenience for applicants.

A more efficient lending process affects credit supply beyond user experience and beyond savings in operational costs. First, FinTech lenders can provide credit more elastically when demand increases, as has been shown in the context of the U.S. mortgage market (Fuster et al. 2019; Fuster et al. 2021). This reflects the increased use of automation as well as the emphasis on centralized operations, which enable labor specialization in the underwriting process (as opposed to an individual underwriter in a branch conducting the entire process) and therefore facilitates capacity adjustments.

\footnotetext{
${ }^{11}$ See https://www.rocketmortgage.com (accessed Aug 30, 2021).

${ }^{12}$ See https://squareup.com/us/ (accessed Aug 30, 2021).
} 
Second, the ability to borrow without any effort required might induce consumers to overborrow, especially when it comes to unsecured loans such as BNPL. In contrast to FinTech lending, traditional credit application processes take significant time and effort. Consumers with a tendency for impulse buying and a taste for immediate gratification can be induced to borrow too much. While self-control problems have been associated with overborrowing for easy-to-use credit cards (see Benton et al. 2007; Heidhues \& Köszegi, 2010), research on the consequences of one-click FinTech lending remains scarce. One exception is the work by Di Maggio \& Yao (2021) who compare default rates between FinTech and bank borrowers using unsecured personal loans. They find that FinTech borrowers become delinquent at substantially higher rates (even controlling for other observable characteristics) and provide evidence that these borrowers use the additional credit not to consolidate existing debt, but to support additional expenditures (such as buying a car).

\subsection{Screening and monitoring}

Takeaway 4: FinTech lenders can improve screening and monitoring by using nontraditional data sources and new methodologies. However, evidence on the extent to which the growth in FinTech lending has been driven by a significant competitive advantage over banks in terms of screening and monitoring is limited.

Various researchers have analyzed the usefulness of nontraditional data sources for credit scoring and lending decisions. A first wave of research made use of publicly available data from marketplace lenders to analyze the usefulness of nontraditional data sources for screening and monitoring of borrowers. These nontraditional data sources and alternative ways of screening include soft information in marketplace lending (Iyer et al. 2016), friendship, social network, group leader data (Hildebrandt et al. 2017; Lin et al. 2013), as well as text-based analysis of applicants listings (Gao et al. 2021; Dorfleitner et al. 2016; Netzer et al. 2019). Most of these papers show that the predictive power of credit scores improves by using nontraditional data sources. However, these results should be interpreted with caution. First, the improvement in the predictive power of credit scores is often lower than the improvement in credit scores brought by relationship-specific information that banks have access to. ${ }^{13}$ Second, an

\footnotetext{
${ }^{13}$ See Mester et al. (2007), Norden \& Weber (2010), and Puri et. al. (2017) for the value of relationship-specific information for credit scoring and lending. Berg et al. (2020) document that bank-internal ratings provide a larger improvement in predictive power than many alternative data sources used in FinTech lending studies. This evidence should be interpreted with care, as results stem from different samples of borrowers. We are not aware
} 
improvement in predictive power does not map one-to-one into a competitive advantage vis-àvis other lenders. Third, many FinTechs innovate both the customer-lender interaction as well as screening and monitoring technology, making it hard to empirically disentangle the effect of better screening and monitoring on the FinTech market share. This cautious note is supported by the fact that - even though many of the papers cited above use marketplace lending data marketplace business models have not been very profitable in practice, as discussed earlier. ${ }^{14}$

A complementary set of studies examine the value of more sophisticated machine learning models for credit scoring and loan performance prediction. The evidence indicates that out-of-sample predictive performance can indeed be improved by the adoption of machine learning when compared to more "traditional" approaches (e.g., Khandani et al. 2010; Gambacorta et al. 2019; Fuster et al. 2021; Sadhwani et al. 2021), although the size of the improvements varies across applications.

The evidence comparing realized delinquency rates between FinTech and bank loans for borrowers with otherwise similar observable characteristics has been mixed. In the U.S. mortgage market, Buchak et al. (2018) find no differences based on data from Fannie Mae and Freddie Mac, while Fuster et al. (2019) find lower delinquency rates for FinTech-originated loans in the riskier FHA segment. In contrast, Di Maggio \& Yao (2021), as discussed above, find higher delinquency rates for FinTech unsecured loans.

A second wave of research has looked into lending by firms that have exclusive access to customer data such as BigTechs, telecommunication firms, E-commerce firms, and payment firms. Cornelli et al. (2020) document that BigTech credit growth has far outstripped credit growth by other FinTech lenders over the past years. Hau et al. (2021) show how a major BigTech in China uses data collected about firms active on its platform to build lending business model, and Gambacorta et al. (2020) find that BigTech credit is much less sensitive to local collateral values than traditional bank lending. Berg et al. (2020) document the use of digital footprints by an E-commerce firms that can track customer behavior on its website. Agarwal et al. (2020) document the use of mobile phone data for credit scoring, while Parlour et al. (2021) and Gosh et al. (2021) highlight complementarities between payment processing and lending.

of any study that would compare predictive power of bank-internal ratings to ratings from FinTech lenders for the same sample of borrowers at the same time.

${ }^{14}$ An alternative way to study the use of alternative data is to examine how much of the variation in the interest rates within a given lender type can be explained by standard information available in credit reports. Buchak et al. (2018) find that for mortgages, the R-squared in regressions of interest rates on standard borrower characteristics is slightly lower for FinTech lenders, potentially in line with these lenders using additional information in their pricing. Di Maggio \& Yao (2021) obtain the opposite result for personal loans, which they interpret as soft information deficiency for FinTech lenders. 
A common theme of this strand of literature is that some firms have a competitive advantage in providing loans to their own customers. In essence, these FinTech business models are not too different from companies providing short-term trade credit, or leasing and financing for their products (see e.g. Murfin \& Pratt, 2019, and Gopal \& Schnabl, 2021, for lending by captive finance subsidiaries). The competitive advantage can arise either from a better ability to screen borrowers, or from a better ability to enforce contracts and to liquidate collateral (e.g. for E-commerce platforms offering loans to merchants selling via their platform). As a drawback, the competitive advantage is typically limited to a specific set of borrowers and may not easily scale beyond the existing customer base.

There is also rising evidence on whether human beings or machines are better at screening and monitoring ("man-vs-machine”). Berg (2015) shows that human loan officers are able to reduce loan default rates by $50 \%$ relative to a lending decision based purely on bankinternal ratings. Costello et al. (2020) provide similar evidence, showing that a combination of machine-generated credit model and human intervention improves loan outcomes relative to the machine-generated credit model. In contrast, Jansen et al. (2021) document that algorithmic underwriting outperforms the human underwriting process, though in a setting where humans only have access to the same set of hard information as the machine. Laudenbach et al. (2021) focus on human involvement in the workout process of consumer loans, and find that personal communication improves recovery rates relative to non-human forms of interaction with the borrower.

It is also worth noting in this context that many lending decisions are much more complicated than just predicting a borrower's default probability as if it were a fixed innate characteristic. Default probabilities are endogenous to loan size, interest rate, maturity and potentially other loan features that the lender can adjust for a given applicant, or that borrowers will endogenously sort into depending on the lender's supply schedule. Furthermore, to maximize profitability, lenders also need to predict loss-given-default, the probability of the borrower taking out another loan in the future, and so forth. It is an open question to what extent FinTech lenders are using randomization (or other techniques to recover causal effects) in order to improve the accuracy of their prediction models out-of-sample. ${ }^{15}$

The relative importance of drivers of FinTech lending growth might also differ across countries. It is plausible that FinTech advances in customer-lender interaction ("convenience") are more important drivers of FinTech credit growth in advanced economies, where screening

\footnotetext{
${ }^{15}$ DeFusco et al. (2021) use data from a Chinese FinTech lender that experimentally cut the cost of consumer installment loans by $40 \%$, presumably to learn about the effects on take-up, loss rates, and profitability.
} 
and monitoring was already rather advanced before the rise of FinTech lending. In countries that were lacking basic data on borrower creditworthiness, FinTech advances are more likely driven by improvements in screening and monitoring. However, cross-country research on the importance of screening/monitoring improvements by FinTech firms is scarce. ${ }^{16}$

\section{Distributional effects}

As the lending landscape changes, a central question is how this affects the distribution of credit, in terms of access to and costs of loans. At least four aspects need to be considered in thinking about this question. First, the reliance on new data can allow assessing the creditworthiness of borrowers that were previously "unscorable," for instance due to a missing credit history. Second, the use of more sophisticated scoring models (on a given set of data) will lead to more dispersion in scores, and thus some borrowers will gain and others lose - the question then being who is in these groups. Third, reliance on algorithmic lending could reduce implicit or explicit biases of human loan officers against certain types of borrowers. Fourth, to the extent that there is advantageous or adverse selection of borrowers into loans by FinTech lenders, this may affect not only the cost of these FinTech loans but also those of traditional lenders (as their set of loan applicants changes). We discuss these issues in turn.

\section{Takeaway 5: The availability of nontraditional data has the potential to expand access to credit for previously excluded borrowers, but direct evidence is scant. Differential privacy preferences across demographic groups could lead to shifts in credit access.}

There is growing evidence that in developing economies, BigTech firms are able to expand credit access to previously unserved or underserved households and firms (e.g. Frost et al. 2019; Hau et al. 2019, 2021), which likely reflects at least in part their access to rich data on these borrowers. ${ }^{17}$ However, direct micro evidence on the role of richer data in changing the distribution of credit is still rather thin. In their study of digital footprints in Germany, Berg et al. (2020) find that the predictive power of the footprint variables for subsequent delinquency was equally strong for otherwise unscorable customers (who did not have a standard credit score) as for scorable ones, suggesting the potential for increased financial inclusion. In

\footnotetext{
${ }^{16}$ Chapter 4 of Amstad et al. (2018) provides a discussion on drivers of FinTech SME lending in Asia. Claessens et al. (2018) and Cornelli et al. (2020) discuss drivers of FinTech credit growth in a cross-country setting.

17 Another possible driver is that BigTechs have more powerful contract enforcement methods than banks. For instance, an SME that does not repay could be excluded from the platform.
} 
practice, when the E-commerce firm studied by Berg et al. (2020) introduced the digital footprint, there was some reshuffling from access to credit from customers who did have a standard credit score in the low-to-medium range but an unfavorable footprint to customers without a standard credit score but a favorable footprint. Jagtiani \& Lemieux (2019) study loans originated by LendingClub over 2007 to 2015 and find that the correlation between borrowers' FICO score and the rating grade assigned by LendingClub decreased steadily over this period, suggesting increased use of alternative data. Using data from Upstart, a FinTech platform in the U.S. that uses alternative data for credit scoring, Di Maggio et al. (2021) provide complementary evidence, showing that borrowers with low standard credit scores and short credit histories have higher acceptance probabilities and pay lower interest rates compared to a traditional lending model.

An important question when it comes to the use of new data for credit scoring is whether every potential borrower's data is automatically available to lenders, or whether the borrower has control over the data that can be accessed. In the latter case, it is possible that differential privacy preferences or trust in (bank and nonbank) financial institutions determine who makes their data available, which in turn affects both the overall informativeness of the data and how the data may impact the distribution of credit. For instance, Tang (2020) finds that loan applicants attach value to not having to disclose a social network ID or employer contact information. Furthermore, women and older applicants are particularly reluctant to disclose such information. The gender gap is also emphasized by Chen et al. (2021), who find based on survey data from 28 countries that women are less willing to share personal data and worry more about their safety; this is likely an important contributor to the documented gender gap in FinTech product use. ${ }^{18}$

Takeaway 6: The use of more sophisticated statistical models aligns credit scores more closely with true underlying default probabilities, which can lead to increased dispersion in credit costs across and within demographic groups. On the other hand, reduced reliance on lending decisions by potentially biased humans can increase credit access for minority groups.

\footnotetext{
18 Armantier et al. (2021) document differences in trust in different types of intermediaries (banks, FinTechs, BigTechs), and that the COVID-19 pandemic has led to a reported decline in the willingness to share personal data. Yang (2021) exploits a negative shock to trust in banks (due to the Wells Fargo scandal) to show that decreased trust in banks leads to faster expansion of FinTech mortgage lending.
} 
Turning to the second issue, the use of more sophisticated scoring models on a given set of data, Fuster et al. (2021) first show formally that under mild assumptions, a move to more sophisticated models (e.g. machine learning models) will increase the dispersion of scores around an unchanged mean, so that some borrowers will "gain" (in the sense of being assessed as less risky than before) while others "lose." They then study in the context of the U.S. mortgage market which groups of society might be most likely to gain if lenders transition from "traditional" technology (in their context, logit models) to more sophisticated machine learning models (random forests or XGBoost). They find that non-Hispanic White and Asian borrowers - groups that already tend to have better access to credit - are more likely to gain than Hispanic and Black borrowers. Furthermore, using a simple credit market equilibrium model, Fuster et al. predict an increase in the dispersion of interest rates across and within these groups, while on the extensive margin (being offered a loan at all) all groups see small improvements. ${ }^{19}$

There are different possible drivers of such unequal effects. One possibility is that the machine learning algorithm uses available borrower characteristics (such as income, credit score, or collateral value) to effectively proxy for, or triangulate, borrowers' race. This would arguably sidestep fair-lending regulation, which does not allow for lending decisions to be based on race and certain other personal characteristics. However, in this application, the study finds that the improved predictive power from machine learning models is primarily due to their increased flexibility to learn how nonlinear combinations of characteristics predict default.

A potential increase in statistical discrimination (even when legal) could be offset by an elimination of taste-based discrimination: FinTech lending can be beneficial for minority groups in the population because human loan officers' biases play less of a role (or no role) when algorithms decide. ${ }^{20} \mathrm{~A}$ study addressing this question in a highly developed market is Bartlett et al. (2021). These authors rely on data from the U.S. mortgage market and use the list of FinTech lenders from Buchak et al. (2018) to study whether loans from these lenders display a lower gap in interest rates between Black and Latinx (minority) groups versus other groups. The results are mixed: for conventional mortgages securitized by Fannie Mae and Freddie Mac, the within-lender rate premia paid by minority borrowers relative to otherwise observationally identical non-minority borrowers are just as large for FinTech lenders as for others. For FHA loans, which are an important financing source for minority borrowers, the rate premia for

\footnotetext{
${ }^{19}$ Huang et al. (2020) compare the effects on predicted default probabilities for Chinese SME loans granted by the FinTech lender MYbank when both non-traditional data and machine learning are used for prediction. They find that the smallest firms are most likely to gain from the move to more data and more sophisticated models, but (unlike when studying the source of performance improvements) do not decompose which aspect is more important for this conclusion.

${ }^{20}$ See Morse \& Pence (2020) for a more extensive discussion of technological innovation and discrimination.
} 
FinTech loans are slightly smaller, suggesting a potential reduction in discrimination. However, the differences between FinTech and non-FinTech lenders are only around 1 basis point (relative to a baseline difference of 4-5 bp for purchase mortgages and 1-2 bp for refinances). ${ }^{21}$

Focusing on potential (rather than realized) effects of replacing human loan officers by algorithmic decisions, Dobbie et al. (2020) reach more optimistic conclusions. Studying data from a high-cost lender in the UK, they document bias against immigrant and older applicants, which they ascribe to an incentive problem (with loan officers maximizing a short-term outcome rather than longer-term profits to the firm). They then show that a decision rule based on machine learning could simultaneously increase profits and eliminate bias. Tantri (2021) conducts a similar analysis in the context of a developing economy (India) where there is much less hard information. Loan officers in this context have access to soft information, which the machine learning model does not have. Nevertheless, the paper finds that an ML algorithm would do better than loan officers in terms of lending efficiency without decreasing the share of loans that go to historically disadvantaged groups. ${ }^{22}$ These results suggest that using the hard information efficiently may more than offset the loss of soft information, and that if there were ML "bias" against disadvantaged groups, this might still be no worse than the bias of human loan officers, whether it arises for misaligned incentives or prejudice/stereotyping.

\section{Takeaway 7: There is little evidence so far, at least in developed economies, that FinTech lenders have extended credit to borrowers previously underserved by banks, except in specialized niche segments.}

Many of the studies above focus on potential impacts of certain features of FinTech lending on the distribution of credit. We now turn to empirical evidence on what has actually happened so far, focusing primarily on the U.S. It appears that FinTech lending has mostly substituted for bank lending, meaning that borrowers who got loans from FinTechs would otherwise likely have been able to obtain them from banks or other sources.

Buchak et al. (2018) and Fuster et al. (2019) study loan- and location-level characteristics to assess whether FinTech mortgage lenders have expanded access to loans for borrowers or in locations with otherwise low access to finance. When looking within non-banks

\footnotetext{
21 The discussed baseline results cover 2009-2015. Using a separate sample covering 2018-19, where the data allow for more precise measurement of total loan costs, there are no significant differences in minority interest premia between FinTech and non-FinTech lenders, although for FHA refinances, FinTech lenders do not charge more to minorities.

${ }^{22}$ Also relying on data from India, D'Acunto et al. (2021) document that the introduction of a robo-advising tool on a peer-to-peer platform substantially reduced lenders' discrimination and improved their performance.
} 
only (in order to hold regulatory influences and financing sources constant), the evidence is mixed: while, for instance, FinTech share is higher in census tracts with lower credit scores, it does not strongly correlate with local or individual income. Also, FinTech market shares are higher in locations with higher bank branch densities and where borrowers are older and more educated, suggesting that obtaining mortgages online may (at least over the period studied, which ended in 2016) be most attractive to experienced borrowers. Consistent with this, FinTech lenders specialized in refinancing and (even within purchase loans) had a lower firsttime homebuyer share than other non-banks.

Jagtiani et al. (2021) study HMDA data for 2016-2019, and find evidence more suggestive of FinTech lenders expanding access to credit. In particular, they find higher FinTech shares in locations with higher application denial rates by non-FinTech lenders in the previous year. Furthermore, based on advertisement and direct mail data, these authors document that FinTech lenders are more likely to reach out to borrowers outside of metropolitan areas. ${ }^{23}$ However, they do not find that FinTech lenders are more likely to make "small-dollar loans" (under \$70,000), even though (if they have lower per-loan origination costs) FinTech lenders should have a comparative advantage to do so.

Di Maggio \& Yao (2021) use credit report data over 2012-17 to study unsecured personal loans. They find that while FinTech lenders in this market initially grew by lending predominantly to low-credit-score borrowers, over time they moved to higher-quality borrowers, although these borrowers tend to have higher credit utilization. FinTech borrowers pay higher interest rates and are more likely to default.

For small business lending, Gopal \& Schnabl (2021) show that FinTech lenders (and other finance companies) gained substantial market share over 2010-2016, and increased their lending the most in areas where the big-4 banks reduced their lending in the wake of the crisis. Balyuk et al. (2020) find that FinTech lending (in their case from two marketplace lenders) tends to substitute for loans by large/out-of-market banks more than small/in-market banks, consistent with FinTechs having a comparative advantage in processing of hard information. On the other hand, Beaumont et al. (2021) find that French FinTech platforms expand credit access of collateral-constrained SMEs by offering them unsecured loans.

These empirical findings should inform further conceptual analysis of the interaction between different lender types (banks, FinTechs, and other shadow banks). The industrial

\footnotetext{
${ }^{23}$ Dolson \& Jagtiani (2021) also use the direct mail offer data to study supply differences between banks, nonbanks and FinTech lenders, for both personal loans and mortgages. They find that overall, FinTech lenders are more likely than banks to send offers to subprime borrowers, while within nonbanks, patterns differ somewhat between personal loans (where there is some evidence of FinTech lenders attempting to "cream-skim") and mortgages.
} 
organization of a lending market may depend, among other things, on different players' regulation, funding, cost structure, and ability to effectively screen and monitor borrowers. But, of course, borrower preferences (in terms of online vs. offline convenience, personal interaction, privacy, etc.) also play an important role. Integrating these factors to understand how equilibrium outcomes may evolve is an important area for further research.

\section{FinTech lending and the COVID-19 pandemic}

The decade after the Global Financial Crisis witnessed few large-scale negative shocks to asset prices or household and firm balance sheets. Thus, the period in which FinTechs grew was a period of stability. The onset of the COVID-19 pandemic in early 2020 changed all this. The pandemic was arguably the first large-scale shock that the newly minted FinTechs had to face. Were FinTech lenders able to maintain the flow of credit, or even expand their market shares? Did defaults of FinTech loans evolve differently from those on bank loans? Research has begun to address these kinds of questions for both advanced and developing economies.

\section{Takeaway 8: FinTechs expanded credit flows in segments where they had continued access to funding during COVID-19, but the pandemic period also revealed vulnerabilities in the FinTech lending approach.}

Fuster et al. (2021) show that FinTech lenders gained market share in the U.S. mortgage market over the course of 2020, especially for loans that are thought to be more time-consuming and complex to underwrite (namely mortgages for new purchases, as opposed to refinances, and to low-credit-score borrowers). ${ }^{24}$ This is consistent with FinTech lenders being better able to scale up (or maintain their lending efficiency) during a time when work-from-home, social distancing etc. made it difficult for traditional lenders to expand their workforce in the face of a strong increase in mortgage demand (primarily for refinancing, fueled by the low long-term interest rates). Given that lender markups were at historical highs over this period (Fuster et al. 2021), this made FinTech mortgage lenders very profitable: for instance, Rocket Mortgage (Quicken)'s parent company reported $\$ 9.5 \mathrm{bn}$ in profits for 2020, relative to under $\$ 1 \mathrm{bn}$ for 2019.

Different FinTech lenders participated in the distribution of loans under the U.S. Paycheck Protection Program (PPP). These loans are partly forgivable to the extent used for

\footnotetext{
${ }^{24}$ The market share of FinTech lenders grew both relative to other non-banks and in the market overall, also because non-banks as a whole gained market share from banks over 2020.
} 
payroll or other allowable expenses and otherwise convert to attractive loans carrying a $1 \%$ interest rate. As the loans are guaranteed by the U.S. Small Business Administration (SBA), they required no underwriting or investments in credit quality assessments. During the initial wave, banks struggled to fulfill the demand for these loans (Balyuk et al. 2021) so the SBA also admitted a number of FinTech lenders to participate. These lenders gained market share in relatively smaller loans, particularly in less banked geographies. As Erel \& Liebersohn (2021) show, the FinTech loans reached areas that were more affected by COVID than bank loans, areas within counties with fewer bank branches, lower income, and higher minority share, and new borrowers without existing bank relationships. Thus, FinTechs seem to have expanded the set of borrowers to those less reachable by traditional banks and not just substituted for otherwise-easily-available bank loans.

There is some evidence that the high PPP market share of FinTechs may have partly reflected lower-quality credit flows by these lenders. Griffin et al. (2021) develop different metrics suggesting potential misreporting on approved PPP loan applications, and find that FinTech loans have a substantially higher incidence of suspicious features than loans from traditional lenders (though the share of loans with suspicious features varies substantially even across FinTech lenders). This suggests that at least for some of the FinTech lenders that participated in this program, many of which were new entrants with little reputation to protect, due diligence processes may have been lacking. ${ }^{25}$

Also, in stark contrast to the important role of FinTechs in originating mortgages and distributing PPP loans, Ben-David et al. (2021) document that "regular" small business lending through a marketplace lending platform came to a halt in March 2020, likely due to the lenders' funding drying up at that time so that lenders became financially constrained. The difference to the mortgage market highlights that funding stability (as is the case in the U.S. mortgage market where most loans are securitized in government-backed pools) is crucial for FinTechs and other nonbanks to maintain the flow of credit during stress situations.

Bao and Huang (2021) compare FinTech and bank loans in China during the pandemic, studying both the distribution of new lending and delinquency rates on pre-existing loans. FinTech lenders increase loan originations more strongly after the start of the pandemic, in particular to borrowers that did not have a previous lending relationship. Furthermore, FinTech loans tilted more toward relatively lower-income borrowers and areas more affected by the

\footnotetext{
${ }^{25}$ Of course, this does not mean that technology itself was not beneficial for lending efficiency over this period. Kwan et al. (2021) use a measure of IT sophistication within banks participating in the PPP and find that more ITsophisticated banks originated more PPP loans within a given location, especially in areas with more severe COVID-19 outbreaks, higher levels of internet use, and higher bank competition.
} 
pandemic, similar in spirit to the PPP findings of Erel \& Liebersohn (2021) discussed above. Turning to loan performance, the study focuses on loans originated prior to but still active at the onset of the pandemic. Delinquency rates remain steady for bank loans but substantially increase for FinTech loans in the six months after the pandemic starts. These differences are only to a small extent explained by observable differences in loan or borrower characteristics. For a subset of borrowers, the authors are able to match FinTech and bank loan records and find that borrowers tend to default on FinTech loans first. Such behavior may reflect a view by borrowers that FinTech loan defaults are less consequential for their future access to credit than bank loan defaults. ${ }^{26}$

\section{Conclusions}

In this paper, we have reviewed the growing literature on FinTech lending - the provision of credit facilitated by technology that improves the customer-lender interaction or lenders' screening and monitoring of borrowers. Our review is a snapshot of where FinTech lending stands as of now. Given the dynamic growth of FinTech lending, the field is likely to develop further, and we see several areas that are important for academics, regulators, and policy makers to closely monitor going forward.

First, adoption of FinTech lending is plausibly path-dependent. Many borrowers have interacted with FinTech lenders for the first time over the past years, and their experiences are likely to shape the adoption of FinTech lending going forward. Have FinTech lenders reaped the low-hanging fruits, with any additional gain in market share becoming subsequently harder to achieve? Or does past FinTech growth fuel future FinTech growth, as borrowers have become acquainted with the new form of financing?

Second, many FinTech lending models have not been tested in protracted recessions, though COVID-19 provided the first glimpse of how FinTech lending performs in turbulent times. If FinTech lending gains a significant market share in many lending markets, cyclicality of loan supply and effects on financial stability will come to the forefront of the discussion among academics, policy makers and regulators.

Third, the growth of FinTech lending has also put FinTech lenders in the spotlight of governments and regulators. Examples include the Woolard Review on unsecured (FinTech) consumer lending in the UK, or the Chinese government's decision to break up Alipay. Regulation is likely to play a significant role for FinTech lending going forward, in particular

\footnotetext{
${ }^{26}$ In a setting with centralized credit reporting like the U.S., this would not be the case, as FinTech and traditional lenders report in the same way.
} 
in areas where FinTech lending has been spurred by a more lenient regulatory treatment vis-àvis established lenders.

Fourth, payment data is of crucial importance for many bank rating models. FinTech payment firms have achieved significant growth in recent years, with examples such as Alipay in China or Paypal, Square and Stripe in the U.S. These payment firms may disrupt access to valuable payment data for traditional banks (Parlour et al. 2020), and may themselves use payment data to screen borrowers, which could in turn further incentivize consumers to use their payment services (Gosh et al. 2021).

Overall, the field of FinTech lending is dynamic and provides a host of important and interesting research questions to answer. The development of the field will impact credit access and welfare of almost all countries, firms, and households worldwide. This review has provided an overview about the current state of research on FinTech lending, as well as guidance on where to look going forward. 


\section{References}

Agarwal S, Alok S, Ghosh P, Gupta S. 2020. Financial Inclusion and Alternate Credit Scoring for the Millennials: Role of Big Data and Machine Learning in Fintech, Working Paper.

Agarwal S, Zhang J. 2020. FinTech, Lending and Payment Innovation: A Review. Asia-Pacific Journal of Financial Studies 49(3), 353-367.

Allen F, Gu X, Jagtiani J. 2021. A Survey of Fintech Research and Policy Discussion. Review of Corporate Finance 1 (3-4), 259-339.

American Banker. 2017. The high-tech, low-effort loans winning over online shoppers. American Banker, July 6, 2017.

Amstad M, Huang B, Moran P J, Shirai S. 2019. Central Bank Digital Currency and Fintech in Asia. Report by the Asian Development Bank Institute.

Armantier O, Doerr S, Frost J, Fuster A, Shue K. 2021. Whom do consumers trust with their data? US survey evidence. BIS Bulletin No 42.

Bank for International Settlements (BIS). 2018. Sound Practices. Implications of FinTech developments for banks and bank supervisors. Basle Committee on Banking Supervision, February 2018.

Balyuk T, Berger A, Hackney J. 2020. What is Fueling FinTech Lending? The Role of Banking Market Structure. Working Paper.

Balyuk T, Davydenko S. 2019, Reintermediation in FinTech: Evidence from Online Lending. Working Paper.

Balyuk T, Prabhala N R, Puri M. 2021. Small Bank Financing and Funding Hesitancy in a Crisis: Evidence from the Paycheck Protection Program. Working Paper.

Bao, Z, Huang D. 2021. Shadow Banking in a Crisis: Evidence from FinTech During COVID19. Journal of Financial and Quantitative Analysis forthcoming.

Barkley B, Schweitzer M. 2021. The Rise of Fintech Lending to Small Businesses: Businesses' Perspectives on Borrowing. International Journal of Central Banking 17(1), 35-65.

Bartlett R, Morse A, Stanton R, Wallace N. 2021. Consumer-lending discrimination in the FinTech Era. Journal of Financial Economics forthcoming.

Basten C, Ongena S. 2020. The Geography of Mortgage Lending in Times of FinTech, CEPR Discussion Paper No. DP14918.

Beaumont P, Tang H, Vansteenberghe E. 2021. The Role of FinTech in Small Business Lending. Working Paper.

Ben-David I, Johnson M, Stulz R M. 2021. Why Did Small Business Fintech Lending Dry Up During March 2020? Fisher College of Business WP 2021-03-014.

Benton M, Meier S, Sprenger C. 2007. Overborrowing and Undersaving: Lessons and Policy Implications from Research in Behavioral Economics, Federal Reserve Bank of Boston Discussion Paper 07-4.

Berg T. 2015. Playing the Devil's Advocate: The Causal Effect of Risk Management on Loan Quality. Review of Financial Studies 28(12), 3367-3406.

Berg, T, Burg V, Gombović A, Puri M. 2020. On the Rise of FinTechs: Credit Scoring using Digital Footprints. Review of Financial Studies 33(7), 2845-2897.

Buchak G, Matvos G, Piskorski T, Seru A. 2018. Fintech, regulatory arbitrage, and the rise of shadow banks. Journal of Financial Economics, 130(3), 453-483. 
Chen S, Doerr S, Frost J, Gambacorta L, Shin H S. 2021. The FinTech gender gap. BIS Working Paper No. 931.

Choi J, Kaul K, Goodman L. 2019. FinTech Innovation in the Home Purchase and Financing Market. Urban Institute Working Paper.

Claessens S, Frost J, Turner G, Zhu F. 2018. Fintech credit markets around the world: size, drivers and policy issues, BIS Quarterly Review, September 2018.

Cornelli G, Frost J, Gambacorta L, Rau R, Wardrop R, Ziegler T. 2020. Fintech and big tech credit: a new data base. BIS Working Paper No. 887.

Costello A, Down A, Mehta M. 2020. Machine + man: A field experiment on the role of discretion in augmenting AI-based lending models, Journal of Accounting and Economics 70(2-3), 1-30.

D'Acunto F, Ghosh P, Jain R, Rossi A G. 2021. How Costly are Cultural Biases? Working Paper.

DeFusco A A, Tang H, Yannelis C. 2021. Measuring the Welfare Cost of Asymmetric Information in Consumer Credit Markets. Working Paper.

Di Maggio M, Ratnadiwakara D, Carmichel D. 2021. Invisible Primes: Fintech Lending with Alternative Data, Working Paper.

Di Maggio M, Yao V. 2021. Fintech Borrowers: Lax-Screening or Cream-Skimming? Review of Financial Studies 34(10), 4546-4618.

Dobbie W A, Liberman A, Paravisini D, Pathania V. 2020. Measuring Bias in Consumer Lending. Review of Economic Studies forthcoming.

Dolson E, Jagtiani J. 2021. Which Lenders Are More Likely to Reach Out to Underserved Consumers: Banks versus Fintechs versus Other Nonbanks? Working Paper 21-17, Federal Reserve Bank of Philadelphia.

Dorfleitner G, Priberny C, Schuster S, Stoiber J, Weber M, de Castro I, Kammler J. 2016. Description-text related soft information in peer-to-peer lending - Evidence from two leading European platforms. Journal of Banking \& Finance 64:169-87.

Erel I, Liebersohn J. 2020. Does Fintech Substitute for Banks? Evidence from the Paycheck Protection Program. NBER Working Paper No. 27659.

Financial Stability Board (FSB). 2019. FinTech and market structure in financial services: Market developments and potential financial stability implications. February 2019.

Frost J, Gambacorta L, Huang Y, Shin H S, Zbinden P. 2019. BigTech and the changing structure of financial intermediation, Economic Policy 34 (100), 761-799.

Fuster A, Plosser M, Schnabl P, Vickery J. 2019. The Role of Technology in Mortgage Lending, Review of Financial Studies 32(5), 1854-1899.

Fuster A, Goldsmith-Pinkham P, Ramadorai T, Walther A. 2021. Predictably Unequal? The Effects of Machine Learning on Credit Markets, Journal of Finance (forthcoming).

Fuster A, Hizmo A, Lambie-Hanson L, Vickery J, Willen P S. 2021. How Resilient is Mortgage Credit Supply? Evidence from the Covid-19 Pandemic. NBER Working Paper No. 28843.

Gambacorta L, Huang Y, Li Z, Qiu H, Chen S. 2020. Data vs. collateral. BIS Working Papers No 881 . 
Gambacorta L, Huang Y, Qiu H, Wang J. 2019. How do machine learning and non-traditional data affect credit scoring? New evidence from a Chinese fintech firm. BIS Working Papers No 834.

Gao Q, Lin M, Sias R. 2021. Words Matter: The Role of Readability, Tone, and Deception Cues in Online Credit Markets. Journal of Financial and Quantitative Analysis (forthcoming).

Ghosh, P., B. Vallee, and Y. Zeng. 2021. FinTech Lending and Cashless Payments, Working Paper.

Gopal M, Schnabl P. 2021. The Rise of Finance Companies and FinTech Lenders in Small Business Lending. Working Paper.

Griffin J M, Kruger S, Mahajan P. 2021. Did FinTech Lenders Facilitate PPP Fraud? Working Paper.

Hau H, Huang Y, Shan H, Sheng Z. 2019. How FinTech Enters China's Credit Market. AEA Papers and Proceedings 109: 60-64.

Hau H, Huang Y, Shan H, Sheng Z. 2021. FinTech Credit and Entrepreneurial Growth. Working paper $N^{o}$ 21-47, Swiss Finance Institute.

Heidhues P, Köszegi B. 2010. Exploiting Naïvete about Self-Control in the Credit Market. American Economic Review 100(5), 2279-2303.

Hildebrandt T, Puri M, Rocholl J. 2017. Adverse incentives in crowdfunding. Management Science 63, 587-608.

Huang Y, Zhang L, Li Z, Qiu H, Sun T, Wang X. 2020. Fintech Credit Risk Assessment for SMEs: Evidence from China. IMF Working Paper WP/20/193.

Iyer R, Khwaja A, Luttmer E, Shue K. 2016. Screening peers softly: Inferring the quality of small borrowers. Management Science 62, 1554-77.

Jagtiani J, Lambie-Hanson L, Lambie-Hanson T. 2021. Fintech Lending and Mortgage Credit Access. The Journal of FinTech 01(01), 2050004.

Jagtiani J, Lemieux C. 2019. The roles of alternative data and machine learning in fintech lending: Evidence from the LendingClub consumer platform. Financial Management 48, 1009-1029.

Jansen M, Nguyen H, Shams A. 2021. Rise of the Machines: The Impact of Automated Underwriting. Fisher College of Business Working Paper No. 2020-03-019.

Khandani A E, Adlar J K, Lo A W. 2010. Consumer credit-risk models via machine-learning algorithms. Journal of Banking \& Finance, 34(11), 2767-2787.

Kwan A, Lin C, Pursiainen V, Tai M. 2021. Stress Testing Banks' Digital Capabilities: Evidence from the COVID-19 Pandemic. Working Paper.

Laudenbach C, Pirschel J, Siegel S. 2021. Personal Communication in a Fintech World: Evidence from Loan Payments. Working Paper.

Lin M, Prabhala N, Viswanathan S. 2013. Judging borrowers by the company they keep: Friendship networks and information asymmetry in online peer-to-peer lending. Management Science 59, 17-35.

Mester L, Nakamura L, Renault M. 2007. Transaction accounts and loan monitoring. Review of Financial Studies 20, 529-56. 
Morse A. 2015. Peer-to-Peer Crowdfunding: Information and the Potential for Disruption in Consumer Lending, Annual Review of Financial Economics 7, 463-482.

Morse A, Pence K. 2020. Technological Innovation and Discrimination in Household Finance. NBER Working Paper No. 26739.

Murfin J, Pratt R. 2019. Who Finances Durable Goods and Why it Matters: Captive Finance and the Coase Conjecture. Journal of Finance 74(2), 755-793.

Netzer O, Lemaire A, Herzenstein M. 2019. When words sweat: Identifying signals for loan default in the text of loan applications. Journal of Marketing Research 56(6), 960-980.

Norden L, Weber M. 2010. Credit line usage, checking account activity, and default risk of bank borrowers. Review of Financial Studies 23, 3665-99.

Parlour C, Rajan U, Zhu H. 2021. When FinTech Competes for Payment Flows. Working Paper.

Puri M, Rocholl J, Steffen S. 2017. What Do A Million Observations Have to Say About Loan Defaults? Opening the Black Box of Relationships. Journal of Financial Intermediation 31, 1-15.

Sadhwani A, Giesecke K, Sirignano J. 2021. Deep Learning for Mortgage Risk. Journal of Financial Econometrics 19(2), 313-368

Stulz R. 2019. FinTech, BigTech, and the Future of Banks. Journal of Applied Corporate Finance 31(4), 86-97.

Tang H. 2020. The Value of Privacy: Evidence from Online Borrowers. Working Paper.

Tantri P. 2021. Fintech for the Poor: Financial Intermediation Without Discrimination. Review of Finance 25(2), 561-593.

Thakor A V. 2019. Fintech and Banking: What do we know? Journal of Financial Intermediation 41, p. 1-13.

TransUnion. 2019. FinTechs Continue to Drive Personal Loan Growth. Report, February 21, 2019.

Vallee B, Zeng Y. 2019. Marketplace Lending: A New Banking Paradigm? Review of Financial Studies 32(5), 1939-1982.

Vives X. 2019. Digital Disruption in Banking. Annual Review of Financial Economics 11:24372.

Yang K. 2021. Trust as an Entry Barrier: Evidence from FinTech Adoption. Working Paper.

Ziegler T, Shneor R, Wenzlaff K, Suresh K, de Camargo Paes F F, Mammadova L, Wanga C, Kekre N, Mutinda S, Wang B W, Closs C L, Zhang B, Forbes H, Soki E, Alam N, Knaup C. 2021. The $2^{\text {nd }}$ Global Alternative Finance Market Benchmarking Report, June 2021. 
Table 1: FinTech lending volumes - The case of the U.S.

This table depicts loan volumes outstanding for the U.S. market (Panel A) as well as loan origination by FinTech lenders in the U.S. (Panels B and Panel C). Sources: Federal Reserve, UCC, HMDA, Jagtiani et al. (2021), Ziegler et al. (2021), Gopal and Schnabl (2021), Annual Reports of LendingClub, Prosper, Quicken Loans, Klarna, Afterpay, and Affirm. For Klarna and Afterpay, we converted stocks into flows using the average duration of the loans provided in the annual reports.

\begin{tabular}{lccc}
\hline \multicolumn{4}{c}{ Panel A: Size of entire lending market (outstanding volumes) } \\
\hline \multicolumn{1}{c}{ Segment } & Source & Q4/2020, USD bn & $\begin{array}{c}\text { Growth p.a. } \\
\mathbf{2 0 1 6 - 2 0 2 0}\end{array}$ \\
\hline Mortgage loans & Federal Reserve & 16,781 & $4.0 \%$ \\
Consumer credit & Federal Reserve & 4,186 & $3.6 \%$ \\
Commercial and & Federal Reserve & 2,600 & $5.7 \%$ \\
Industrial loans & & &
\end{tabular}

\begin{tabular}{lccc}
\hline \multicolumn{4}{c}{ Panel B: Estimates of FinTech lending (new lending) } \\
\multicolumn{1}{c}{ Segment } & Source & 2020, USD bn & $\begin{array}{c}\text { Growth p.a. } \\
\mathbf{2 0 1 6 - 2 0 2 0}\end{array}$ \\
\hline $\begin{array}{l}\text { FinTech mortgage } \\
\text { lending }\end{array}$ & $\begin{array}{c}\text { Jagtiani et al. (2021) } \\
\text { FinTech consumer }\end{array}$ & 565 & $32.5 \% \%^{\mathrm{a}}$ \\
$\begin{array}{l}\text { lending } \\
\text { FinTech business lending }\end{array}$ & Ziegler et al. (2021) & 38 & \\
& Ziegler et al. (2021) & 31 & $11.9 \%$ \\
& & & $43.1 \%$
\end{tabular}

\begin{tabular}{|c|c|c|c|}
\hline \multicolumn{4}{|c|}{ Panel C: FinTech lending for subsegments and for major players (new lending) } \\
\hline Segment & Source & 2020, USD bn & $\begin{array}{c}\text { Growth p.a. } \\
2016-2020\end{array}$ \\
\hline $\begin{array}{l}\text { Rocket Mortgage } \\
\text { (formerly Quicken } \\
\text { Loans) }\end{array}$ & Annual Reports & 320 & $35 \%$ \\
\hline $\begin{array}{l}\text { Secured non-real-estate } \\
\text { C\&I loans by FinTech } \\
\text { lenders ("UCC data") }\end{array}$ & $\begin{array}{l}\text { Gopal and Schnabl } \\
(2021), \text { own } \\
\text { calculations } \\
\end{array}$ & 11 & $11 \%$ \\
\hline LendingClub & Annual Reports & 4 & $-16 \%$ \\
\hline Prosper & Annual Reports & 2 & $-9 \%$ \\
\hline $\begin{array}{l}\text { Buy-Now-Pay-Later } \\
\text { (BNPL): Klarna, } \\
\text { Afterpay, and Affirm } \\
\text { combined }\end{array}$ & $\begin{array}{c}\text { Annual Reports } \\
\text { Klarna, Afterpay, } \\
\text { Affirm }\end{array}$ & 25 & $>100 \%$ \\
\hline
\end{tabular}


Table 2: Market capitalization / valuation of FinTech lenders

This table depicts the market capitalization as of August 30, 2021 of a selective set of FinTechs that have a significant activity in the U.S. For non-listed firms, the valuation is based on the latest funding round or takeover date. Source: Refinitv/Datastream, Reuters.

Firm Valuation USD bn Date and type

FinTechs in the mortgage market with significant activities in the U.S.

Rocket Companies $\quad 35.2 \quad$ Market capitalization

FinTechs in the marketplace lending market with significant activities in the U.S.

LendingClub $\quad 2.8 \quad$ Market capitalization

Prosper $\quad<1.0 \quad$ Latest funding round (Sep 2017)

OnDeck $\quad 0.1 \quad$ Deal value (acquired by Enova on Oct 13, 2020)

FinTechs in the BNPL market with significant activities in the U.S.

$\begin{array}{lcl}\text { Klarna } & 45.6 & \text { Funding round (June 2021) } \\ \text { Afterpay } & 29.0 & \begin{array}{l}\text { Deal value (takeover announced by Square on } \\ \text { Aug 2, 2021) }\end{array} \\ \text { Affirm } & 18.0 & \text { Market capitalization }\end{array}$

